\title{
Contamination of expressed human breast milk with an epidemic multiresistant Staphylococcus aureus clone
}

\author{
F. R. NOVAK*†, A. V. DA SILVA*, A. N. HAGLER* and A. M. S. FIGUEIREDO* \\ * Universidade Federal do Rio de Janeiro, Instituto de Microbiologia Prof. Paulo de Góes, CCS, BI I, Cidade \\ Universitária, Rio de Janeiro, RJ and †Instituto Fernandes Figueira, Banco de Leite Humano, Av. Rui Barbosa, \\ 716, Flamengo, Rio de Janeiro, RJ, Brazil
}

\begin{abstract}
Nosocomial infections caused by methicillin-resistant Staphylococcus aureus (MRSA) are a major cause of outbreaks in intensive care units. Infants make up a sector of the population that presents a high risk for MRSA infections. Mother-to-infant transmission has been indicated as a possible cause of MRSA infections in neonates. The occurrence and characteristics of MRSA in samples of banked human milk were investigated by selective culture, antibiogram and pulsed-field gel electrophoresis. MRSA contamination was found in $11 \%$ of 500 samples of expressed, fresh-frozen milk from 500 different donors at five Brazilian milk banks. The great majority of the contaminated samples passed breast milk quality control criteria for dispensing as raw milk under Brazilian and American guidelines. Most of the MRSA isolates belonged to the Brazilian epidemic clone, which is reported to be widespread in several Brazilian states, in Argentina and in Portugal. It is concluded that expressed breast milk can be a reservoir of multiresistant $S$. aureus epidemic clones. Studies are necessary to assess the source of contamination and potential role of MRSA-contaminated milk in the transmission of MRSA to neonates.
\end{abstract}

\section{Introduction}

Staphylococcus aureus is carried by c. $30 \%$ of human beings as indigenous flora $[1,2]$. This micro-organism can cause a broad spectrum of infections in children and adults, varying from a simple skin lesion to disseminated disease as bacteraemia. Nosocomial infections by both methicillin-resistant $S$. aureus (MRSA) and methicillin-susceptible (MSSA) organisms are well documented [3-6]. Although MRSA hospital-acquired infections have been a problem since the 1970 s, it only recently became a major cause of outbreaks in neonatal intensive care units (NICU) [58]. The spectrum of infections in infants includes pneumonia, osteomyelitis, bacteraemia, meningitis and skin infections, ranging from minor localised diseases to the more severe scalded skin syndrome $[8,9]$.

Received 30 May 1999; revised version received 27 Jan. 2000; accepted 13 March 2000.

Corresponding author: Dr A. M. S. Figueiredo. Present address: Skirball Institute of Biomolecular Medicine, New York University Medical Center, 550 First Avenue, New York, NY 10016, USA.
Infants in NICU are among the population that presents a higher risk for MRSA diseases. New-born babies are compromised hosts for whom MRSA carriage implies a high risk of MRSA infection. Because of the difficulties in controlling MRSA in this setting, extended outbreaks can cause significant morbidity and mortality [7].

Many factors contribute to MRSA infections in NICU patients: neonatal prematurity, respiratory syndromes, intra-vascular catheters, exposure to antibiotics and long periods of hospitalisation. Indeed, premature infants are more likely to stay for an extended period in the unit, serving as a continuing reservoir for crossinfections [10]. Several studies have reported the occurrence of familial carriage of MRSA with subsequent infections in full-term and premature neonates [11-15].

Human milk is considered to be the best food for infants; it contains all the nutrients they need and also helps to protect them against infection $[16,17]$. Healthcare professionals generally agree that properly collected and stored human milk is appropriate for healthy full-term and pre-term babies [1]. However, for num- 
erous reasons breast-feeding can be impossible or inadvisable. Furthermore, there is controversy regarding the safety and suitability of banked milk for ill or pre-term infants [16].

The fact that mothers may serve as reservoirs for MRSA infection raises an important issue for hospital infection control which was addressed in the present study: can fresh-frozen breast milk be contaminated with MRSA epidemic clones?

\section{Materials and methods}

\section{Human milk banks}

The milk banks involved in this study belong to $200-$ 300-bed university hospitals and are located close to the hospital entrance and separated from other hospital facilities. Donor milk is given voluntarily by women from the community or by the mothers delivered in the hospital. Guidelines for the operation of the milk banks in Brazil were established by the Ministry of Health [18] and are very similar to the guidelines recommended by the Human Milk Banking Association of North America [19].

\section{Breast milk samples}

Fresh-frozen milk samples (100) from 100 mothers were obtained from each of five human milk banks located in different Brazilian states: Maternidade Escola Januário Cicco, Natal, RN (MEJC; Northeast); Maternidade Escola Assis Chateaubriant, Fortaleza, CE (MEAC; Northeast); Instituto Fernandes Figueira, Rio de Janeiro, RJ (IFF; Southeast); Universidade de Brasilia, Brasilia, DF (UB; Midwest) and Universidade Estadual de Londrina, Londrina, PR (UEL; South).

To ensure the optimum quality of milk, the donors were instructed in the appropriate methods for sanitary collection, handling, storage and transportation of the breast milk. The protocols provided for clean technique include the following items: (a) careful washing (water and detergent) and boiling $\left(100^{\circ} \mathrm{C} / 10 \mathrm{~min}\right)$ of the breast pump components, (b) hand washing and cleansing of the breasts and (c) handling sterile containers provided by the milk bank. Finally, the donors were instructed concerning labelling, freezing, storage and transportation of the milk to the milk bank. In the milk bank, the milk was processed according to a detailed protocol. The collection was carried out in the hospital, at the milk bank or at home.

\section{Transportation}

Samples $(5 \mathrm{ml})$ of expressed, fresh-frozen milk, were transported frozen on dry ice from the milk banks to the laboratory. The transportation was completed in a maximum of $5 \mathrm{~h}$ and the milk was processed immediately after delivery.

\section{Bacteriological screening}

Each sample of breast milk was screened for contamination by normal skin flora as follows: samples $(0.1 \mathrm{ml})$ and appropriate dilutions were inoculated in duplicate on Baird-Parker's agar. After incubation at $37^{\circ} \mathrm{C}$ for $24-48 \mathrm{~h}$, the colonies presenting morphological characteristics of staphylococci were counted. Milk acceptable for dispensing raw should contain $<10^{4} \mathrm{cfu} / \mathrm{ml}$ [19].

\section{Processing of the samples}

A $0.5-\mathrm{ml}$ sample of breast milk was inoculated into $5 \mathrm{ml}$ of a methicillin-containing broth (MB) which was incubated at $35^{\circ} \mathrm{C}$ for $48 \mathrm{~h}$. MB broth consisted of trypticase soy broth (TSB) with $\mathrm{NaCl} 7.5 \% \mathrm{w} / \mathrm{v}$ (to inhibit the growth of non-haloduric bacteria) and methicillin $10 \mathrm{mg} / \mathrm{L}$ (to select for the low population of methicillin-resistant bacteria). After incubation, the culture was streaked on trypticase soy agar (TSA) and the plates were incubated at $35^{\circ} \mathrm{C}$ for $18-24 \mathrm{~h}$. Five colonies with morphological characteristics of staphylococci were inoculated into a tube containing TSB. The cultures were grown at $35^{\circ} \mathrm{C}$ for $18 \mathrm{~h}$, with vigorous shaking $\left(c .10^{10} \mathrm{cfu} / \mathrm{ml}\right)$ and used for $S$. aureus identification and MRSA detection.

\section{Identification of S. aureus}

The strains isolated were identified as $S$. aureus by routine tests (Gram's staining, catalase and free coagulase tests) [20] and stored at $-70^{\circ} \mathrm{C}$ in sterile glycerol $12 \% \mathrm{w} / \mathrm{v}$ (final concentration).

\section{Methicillin agar screen}

A $100-\mu 1$ volume of the culture described above was inoculated on TSA plates containing methicillin $25 \mathrm{mg}$ / L [21]. If growth was observed, a single colony from the culture described above was obtained to confirm the staphylococcal presumptive identification and the methicillin resistance, as described. Glycerol (10\% $\mathrm{v} / \mathrm{v}$, final concentration) stock of the culture obtained from the single colony was frozen at $-70^{\circ} \mathrm{C}$.

This methicillin screen agar has been shown to be very sensitive for the detection of MRSA [21]. MRSA heterogeneous resistant isolates belonging to classes I and II, that have small methicillin-resistant subpopulations $\left(c\right.$. $\left.10^{-5}-10^{-8}\right)$, were detected by this agar screen, although these isolates failed to be detected by other NCCLS recommended tests [21]. The combination of high inoculum (that allows the detection of small resistant subpopulations) and methicillin at $25 \mathrm{mg} / \mathrm{L}$ (a concentration high enough to impair the growth of borderline methicillin-resistant $S$. aureus but low enough to allow the growth of any truly resistant isolate) are the factors responsible for a complete 
agreement of this test with the detection of mecA gene with a specific MRSA probe [21].

\section{Disk diffusion method}

Disk diffusion tests were performed as recommended by the National Committee for Clinical Laboratory Standards (NCCLS) [22]. Disks containing the following antimicrobial agents (Cecon, São Paulo, Brazil) were used: oxacillin $1 \mu \mathrm{g}$, penicillin $10 \mathrm{U}$, clindamycin $2 \mu \mathrm{g}$, chloramphenicol $30 \mu \mathrm{g}$, ciprofloxacin $5 \mu \mathrm{g}$, tetracycline $30 \mu \mathrm{g}$, gentamicin $10 \mu \mathrm{g}$, trimethoprimsulphamethoxazole $1.25-23.75 \mu \mathrm{g}$ and vancomycin $30 \mu \mathrm{g}$. The 5- $\mu \mathrm{g}$ mupirocin disk was from Oxoid.

\section{Bacterial growth in expressed breast milk}

A milk sample obtained $<3$ days postpartum (colostrum) was inoculated with MRSA isolates to determine the rate of bacterial growth in expressed breast milk. Frozen stocks of MRSA strains, previously isolated from contaminated breast milk, were inoculated in $2 \mathrm{ml}$ of TSB. After incubation $\left(37^{\circ} \mathrm{C}\right.$ for $\left.24 \mathrm{~h}\right)$, the culture was centrifuged and washed twice in the same medium. The pellet was suspended in fresh TSA and an inoculum containing c. $2 \times 10^{4} \mathrm{cfu} / \mathrm{ml}$ was simultaneously inoculated in TSA $(40 \mathrm{ml})$ and in colostrum $(40 \mathrm{ml})$. The cultures were incubated at $37^{\circ} \mathrm{C}$ for $24 \mathrm{~h}$. Samples of the bacterial growth were collected at time zero and at each 3-h interval for determination of viable count $(\mathrm{cfu} / \mathrm{ml})$.

\section{DNA preparation}

All the procedures for $S$. aureus DNA preparation were as described previously [23] except that the staphylococcal cell wall was lysed with lysostaphin $90 \mathrm{U} / \mathrm{ml}$. The Escherichia coli plasmid DNA was prepared with the Flex-Prep kit (Pharmacia Biotechnology, Uppsala, Sweden), as recommended by the manufacturer. The DNA fragment of $E$. coli plasmid (used as probe) was purified from an agarose $0.8 \%$ DNA electrophoresis gel, with the Sephaglas Band Prep kit (Pharmacia Biotechnology), as recommended. DNA in solution was transferred on to nylon membrane with the Bio-Dot unit as described by the manufacturer (BioRad, Hercules, CA, USA).

\section{Probe preparation}

The DNA probe used was a 1250-bp Pst I-Xba I fragment of the mecA gene cloned into pTZ219 [24]. The procedures to obtain the fluorescein-labelled probe by the Enhanced Chemiluminescence (ECL) Gene Labelling System and to hybridise the nylon-bound DNA were performed as recommended by the manufacturer (Amersham, Little Chalfont, Bucks).

\section{Pulsed-field gel electrophoresis system}

Genomic DNA was prepared and digested with SmaI restriction enzyme as described previously [21]. Pulsed-field gel electrophoresis (PFGE) was performed as described [2] in a CHEF DR III apparatus (BioRad), except that the voltage applied was $5.5 \mathrm{~V} / \mathrm{cm}$. Methods used for staining, photographing, Southern hybridisation and probing of the gels have been described previously [23]. The criteria used to analyse the pulsedfield bands and define clonality were also as described previously [25].

\section{Results}

\section{Screening for MRSA isolates}

A total of 57 MRSA strains was isolated from 500 samples of fresh-frozen breast milk, after enrichment in a medium containing methicillin $10 \mathrm{mg} / \mathrm{L}$ and subsequent screening on methicillin agar containing $25 \mathrm{mg}$ of the drug/L. The highest proportion of MRSA contamination (27\%) was obtained from MEJC, the Natal milk bank, whereas in the other four banks analysed the percentage of MRSA contamination was lower (Fig. 1a). The increased MRSA contamination in MEJC was in parallel with the increase observed in the total S. aureus (MRSA and MSSA isolates) recovered from milk samples. Only $44 \%$ of milk samples from MEJC had no contamination with staphylococci. Furthermore, the samples obtained from the other milk banks analysed had a higher percentage of absence of staphylococcal contamination varying from 79\% (UB milk bank) to $62 \%$ (MEAC; Fig. 1a).

Nevertheless, the majority of milk samples with MRSA contamination had a staphylococcal viable count of $<10^{4} \mathrm{cfu} / \mathrm{ml}$. Therefore, the great majority of the milk samples met the criteria to be dispensed as raw milk (under both Brazilian and American guidelines), with the exception of only three samples (Fig. 1b).

All MRSA isolates showed resistance to a high level of methicillin by growing confluently around the edge of a $1-\mu \mathrm{g}$ oxacillin disk and on methicillin $25 \mathrm{mg} / \mathrm{L}$ plates. The presence of the mecA gene in these isolates was confirmed by using an internal fragment of this gene as probe (Fig. 1c). The 57 MRSA isolates were also resistant to the great majority of antimicrobial drugs tested, except vancomycin and mupirocin (Table 1).

\section{Rate of bacterial growth in colostrum}

The two MRSA isolates from the Brazilian epidemic clone tested (strains 166 and 365) grew efficiently in colostrum. The inhibitory effect of colostrum, if significant, was minimal. With a starting culture of $c$. $5 \times 10^{2} \mathrm{cfu} / \mathrm{ml}$, the bacterial growth reached $c .10^{8} \mathrm{cfu} /$ $\mathrm{ml}$ in colostrum after incubation for $24 \mathrm{~h}$ at $37^{\circ} \mathrm{C}$, only $0.4 \log _{10}$ (strain 166) - $1.1 \log _{10}$ (strain 365) less than 
a

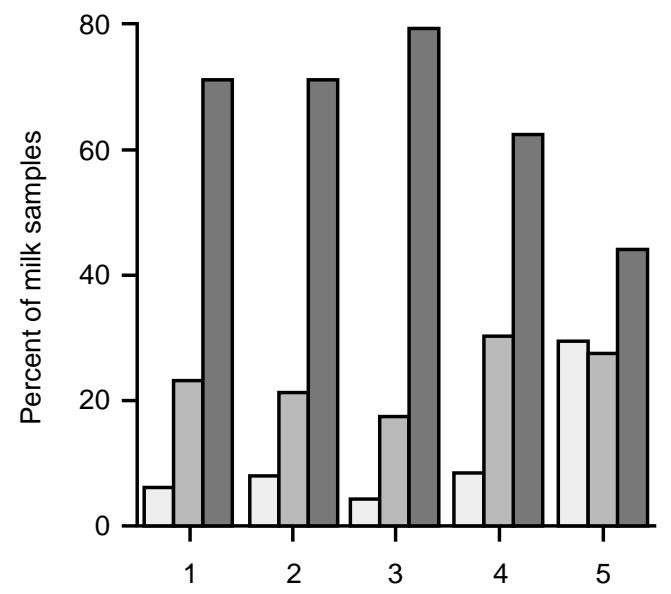

b

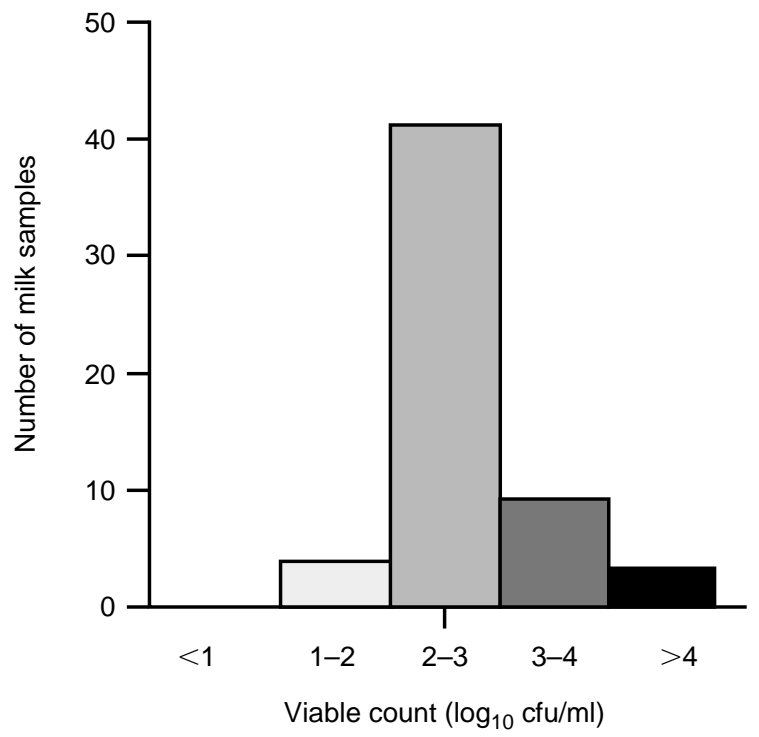

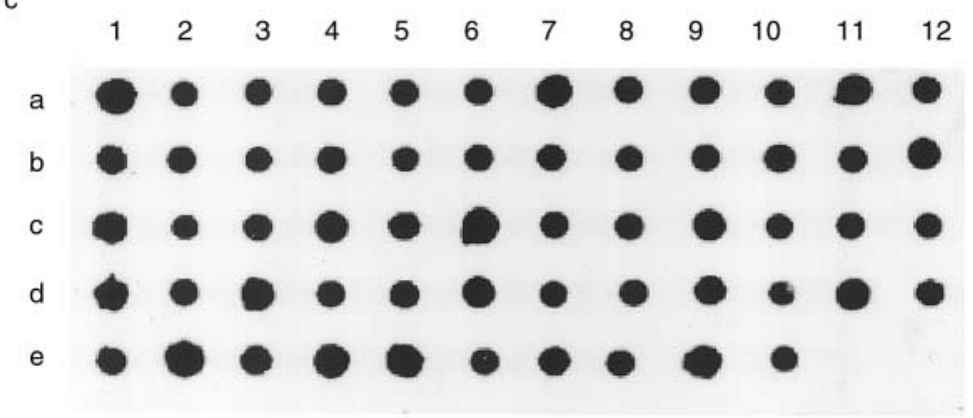

Fig. 1. (a) Percentage of MRSA contamination ( $\square$ ), S. aureus contamination ( $\square$ ) and no contamination ( $\square$ ) in 500 freshfrozen milk samples obtained from Brazilian milk banks (column 1, UEL; 2, IFF; 3, UB; 4, MEAC; 5, MEJC). (b) viable count $(\mathrm{cfu} / \mathrm{ml})$ of normal skin flora contaminants (represented by Staphylococcus spp.) detected in 500 freshfrozen human milk samples. (c) Dot-blot hybridisation of S. aureus genomic DNA with a specific mecA probe: 1-9, MRSA strains isolated from Brazilian milk banks, as presented in Table 1; 10, MRSA strain designated as Col (positive control for the probe); 11, MSSA strain used as negative control.

the growth observed when the same isolates were grown in TSB (Fig. 2).

\section{Clonality of MRSA isolates}

The analysis of restriction fragment length polymorphism (RFLP) after chromosomal DNA digestion with the endonuclease SmaI and separation of fragments by PFGE showed that 40 of 57 MRSA isolates studied had the same pattern (assigned here as pattern $A_{1}$ ) which was that of a 'super' epidemic, multiresistant MRSA clone (Table 1; Fig. 3a) that has been incriminated as a major cause of staphylococcal hospital infections in Brazil, Argentina and Portugal [2, 26-28]. Furthermore, six MRSA isolates belonged to subclones of this epidemic clone, differing in one-to-three pulsed-field bands. The other 11 isolates belonged to seven unique PFGE patterns (Table 1; Fig. 3b). Among them, the clonal type $\mathrm{B}$ was found in three different regions studied (Southeast, Northeast and Midwest) and clonal type $\mathrm{C}$ in two regions (Southeast and Northeast).

\section{Discussion}

As MRSA is endemic in many Brazilian hospitals [27] and deliveries are frequently carried out in hospitals, breast milk might be expected to be occasionally contaminated with multiresistant $S$. aureus clones. To address this question, the present study investigated the presence of MRSA in 500 samples of expressed breast milk obtained from five milk banks located in different Brazilian states. A very sensitive methodology involving enrichment of resistant isolates was used and detected a high level of MRSA contamination ( $c$. $11 \%$ ). In addition, all the MRSA isolates were multiresistant to the majority of antimicrobial agents tested.

Only three of 57 milk samples that contained MRSA had a high level $\left(>10^{4}\right)$ of contamination with skin flora. Thus, it is clear that the high percentage of MRSA contamination in the other 54 milk samples analysed was not the consequence of a high level of skin flora contamination due to problems in breast milk 
Table 1. Antimicrobial susceptibility and PFGE patterns of MRSA isolates from expressed breast milk, obtained from different milk banks in Brazil

\begin{tabular}{|c|c|c|c|c|c|c|c|c|c|c|c|c|}
\hline \multirow{2}{*}{$\begin{array}{l}\text { Strain } \\
\text { no. }\end{array}$} & \multirow{2}{*}{$\begin{array}{l}\text { Milk } \\
\text { bank }^{\dagger}\end{array}$} & \multirow[b]{2}{*}{$\mathrm{PFGE}^{*}$} & \multicolumn{10}{|c|}{ Antimicrobial drug* susceptibility } \\
\hline & & & $\mathrm{Cl}$ & Mup & $\mathrm{Vc}$ & Sft & Cip & Co & Gn & Ox & Pn & $\mathrm{Tc}$ \\
\hline 19 & IFF & A1 & $\mathrm{R}$ & $\mathrm{S}$ & $\mathrm{S}$ & $\mathrm{R}$ & $\mathrm{R}$ & $\mathrm{R}$ & $\mathrm{R}$ & $\mathrm{R}$ & $\mathrm{R}$ & $\mathrm{R}$ \\
\hline 99 & & B & $\mathrm{R}$ & $\mathrm{S}$ & $\mathrm{S}$ & $\mathrm{S}$ & $\mathrm{R}$ & $\mathrm{R}$ & $\mathrm{R}$ & $\mathrm{R}$ & $\mathrm{R}$ & $\mathrm{R}$ \\
\hline 120 & & $\mathrm{D}$ & $\mathrm{S}$ & $\mathrm{S}$ & $\mathrm{S}$ & $\mathrm{R}$ & $\mathrm{R}$ & $\mathrm{R}$ & $\mathrm{R}$ & $\mathrm{R}$ & $\mathrm{R}$ & $\mathrm{R}$ \\
\hline 121 & & E & $\mathrm{S}$ & $\mathrm{S}$ & $\mathrm{S}$ & $\mathrm{R}$ & $\mathrm{R}$ & $\mathrm{R}$ & $\mathrm{R}$ & $\mathrm{R}$ & $\mathrm{R}$ & $\mathrm{S}$ \\
\hline 149 & & F & $\mathrm{S}$ & $\mathrm{S}$ & $\mathrm{S}$ & $\mathrm{R}$ & $\mathrm{R}$ & $\mathrm{R}$ & $\mathrm{R}$ & $\mathrm{R}$ & $\mathrm{R}$ & $\mathrm{S}$ \\
\hline 166 & & A1 & $\mathrm{R}$ & $\mathrm{S}$ & $\mathrm{S}$ & $\mathrm{R}$ & $\mathrm{R}$ & $\mathrm{R}$ & $\mathrm{R}$ & $\mathrm{R}$ & $\mathrm{R}$ & $\mathrm{R}$ \\
\hline 175 & & $\mathrm{C}$ & $\mathrm{R}$ & $\mathrm{S}$ & $\mathrm{S}$ & $\mathrm{R}$ & $\mathrm{R}$ & $\mathrm{R}$ & $\mathrm{R}$ & $\mathrm{R}$ & $\mathrm{R}$ & $\mathrm{R}$ \\
\hline 182 & & A2 & $\mathrm{R}$ & $\mathrm{S}$ & $\mathrm{S}$ & $\mathrm{R}$ & $\mathrm{R}$ & $\mathrm{R}$ & $\mathrm{R}$ & $\mathrm{R}$ & $\mathrm{R}$ & $\mathrm{R}$ \\
\hline 215 & MEJC & A1 & $\mathrm{R}$ & $\mathrm{S}$ & $\mathrm{S}$ & $\mathrm{R}$ & $\mathrm{R}$ & $\mathrm{R}$ & $\mathrm{R}$ & $\mathrm{R}$ & $\mathrm{R}$ & $\mathrm{R}$ \\
\hline 241 & & $\mathrm{~A} 1$ & $\mathrm{R}$ & $\mathrm{S}$ & $\mathrm{S}$ & $\mathrm{R}$ & $\mathrm{R}$ & $\mathrm{R}$ & $\mathrm{R}$ & $\mathrm{R}$ & $\mathrm{R}$ & $\mathrm{R}$ \\
\hline 244 & & Al & $\mathrm{R}$ & $\mathrm{S}$ & $\mathrm{S}$ & $\mathrm{R}$ & $\mathrm{R}$ & $\mathrm{R}$ & $\mathrm{R}$ & $\mathrm{R}$ & $\mathrm{R}$ & $\mathrm{R}$ \\
\hline 245 & & $\mathrm{~A} 1$ & $\mathrm{R}$ & $\mathrm{S}$ & $\mathrm{S}$ & $\mathrm{R}$ & $\mathrm{R}$ & $\mathrm{R}$ & $\mathrm{R}$ & $\mathrm{R}$ & $\mathrm{R}$ & $\mathrm{R}$ \\
\hline 260 & & B & $\mathrm{S}$ & $\mathrm{S}$ & $\mathrm{S}$ & $\mathrm{S}$ & $\mathrm{R}$ & $\mathrm{R}$ & $\mathrm{R}$ & $\mathrm{R}$ & $\mathrm{R}$ & $\mathrm{R}$ \\
\hline 275 & & $\mathrm{~A} 1$ & $\mathrm{R}$ & $\mathrm{S}$ & $\mathrm{S}$ & $\mathrm{R}$ & $\mathrm{R}$ & $\mathrm{R}$ & $\mathrm{R}$ & $\mathrm{R}$ & $\mathrm{R}$ & $\mathrm{R}$ \\
\hline 278 & & $\mathrm{~A} 1$ & $\mathrm{R}$ & $\mathrm{S}$ & $\mathrm{S}$ & $\mathrm{R}$ & $\mathrm{R}$ & $\mathrm{R}$ & $\mathrm{R}$ & $\mathrm{R}$ & $\mathrm{R}$ & $\mathrm{R}$ \\
\hline 289 & & A3 & $\mathrm{R}$ & $\mathrm{S}$ & $\mathrm{S}$ & $\mathrm{R}$ & $\mathrm{R}$ & $\mathrm{R}$ & $\mathrm{R}$ & $\mathrm{R}$ & $\mathrm{R}$ & $\mathrm{R}$ \\
\hline 295 & & A1 & $\mathrm{R}$ & $\mathrm{S}$ & $\mathrm{S}$ & $\mathrm{R}$ & $\mathrm{R}$ & $\mathrm{R}$ & $\mathrm{R}$ & $\mathrm{R}$ & $\mathrm{R}$ & $\mathrm{R}$ \\
\hline 296 & & $\mathrm{C}$ & $\mathrm{S}$ & $\mathrm{S}$ & $\mathrm{S}$ & $\mathrm{R}$ & $\mathrm{S}$ & $\mathrm{R}$ & $\mathrm{R}$ & $\mathrm{R}$ & $\mathrm{R}$ & $\mathrm{R}$ \\
\hline 304 & MEAC & A1 & $\mathrm{R}$ & $\mathrm{S}$ & $\mathrm{S}$ & $\mathrm{R}$ & $\mathrm{R}$ & $\mathrm{R}$ & $\mathrm{R}$ & $\mathrm{R}$ & $\mathrm{R}$ & $\mathrm{R}$ \\
\hline 308 & & A4 & $\mathrm{R}$ & S & $\mathrm{S}$ & $\mathrm{R}$ & $\mathrm{R}$ & $\mathrm{R}$ & $\mathrm{R}$ & $\mathrm{R}$ & $\mathrm{R}$ & $\mathrm{R}$ \\
\hline 314 & & $\mathrm{~A} 1$ & $\mathrm{~S}$ & $\mathrm{~S}$ & $\mathrm{~S}$ & $\mathrm{R}$ & $\mathrm{S}$ & $\mathrm{R}$ & $\mathrm{R}$ & $\mathrm{R}$ & $\mathrm{R}$ & $\mathrm{R}$ \\
\hline 317 & & A1 & $\mathrm{R}$ & S & $\mathrm{S}$ & $\mathrm{R}$ & $\mathrm{R}$ & $\mathrm{R}$ & $\mathrm{R}$ & $\mathrm{R}$ & $\mathrm{R}$ & $\mathrm{R}$ \\
\hline 320 & & A1 & $\mathrm{R}$ & $\mathrm{S}$ & $\mathrm{S}$ & $\mathrm{S}$ & $\mathrm{R}$ & $\mathrm{R}$ & $\mathrm{R}$ & $\mathrm{R}$ & $\mathrm{R}$ & $\mathrm{R}$ \\
\hline 327 & & $\mathrm{~A} 1$ & $\mathrm{R}$ & $\mathrm{S}$ & $\mathrm{S}$ & $\mathrm{R}$ & $\mathrm{R}$ & $\mathrm{R}$ & $\mathrm{R}$ & $\mathrm{R}$ & $\mathrm{R}$ & $\mathrm{R}$ \\
\hline 328 & & A1 & $\mathrm{R}$ & $\mathrm{S}$ & $\mathrm{S}$ & $\mathrm{R}$ & $\mathrm{R}$ & $\mathrm{R}$ & $\mathrm{R}$ & $\mathrm{R}$ & $\mathrm{R}$ & $\mathrm{R}$ \\
\hline 329 & & A1 & $\mathrm{R}$ & $\mathrm{S}$ & $\mathrm{S}$ & $\mathrm{R}$ & $\mathrm{R}$ & $\mathrm{R}$ & $\mathrm{R}$ & $\mathrm{R}$ & $\mathrm{R}$ & $\mathrm{R}$ \\
\hline 332 & & A1 & $\mathrm{R}$ & $\mathrm{S}$ & $\mathrm{S}$ & $\mathrm{R}$ & $\mathrm{R}$ & $\mathrm{R}$ & $\mathrm{R}$ & $\mathrm{R}$ & $\mathrm{R}$ & $\mathrm{R}$ \\
\hline 340 & & $\mathrm{~A} 1$ & $\mathrm{R}$ & $\mathrm{S}$ & $\mathrm{S}$ & $\mathrm{R}$ & $\mathrm{R}$ & $\mathrm{R}$ & $\mathrm{R}$ & $\mathrm{R}$ & $\mathrm{R}$ & $\mathrm{R}$ \\
\hline 344 & & A1 & $\mathrm{R}$ & $\mathrm{S}$ & $\mathrm{S}$ & $\mathrm{R}$ & $\mathrm{R}$ & $\mathrm{R}$ & $\mathrm{R}$ & $\mathrm{R}$ & $\mathrm{R}$ & $\mathrm{R}$ \\
\hline 349 & & $\mathrm{~A} 1$ & $\mathrm{R}$ & $\mathrm{S}$ & $\mathrm{S}$ & $\mathrm{R}$ & $\mathrm{R}$ & $\mathrm{R}$ & $\mathrm{R}$ & $\mathrm{R}$ & $\mathrm{R}$ & $\mathrm{R}$ \\
\hline 352 & & A1 & $\mathrm{R}$ & S & $\mathrm{S}$ & $\mathrm{R}$ & $\mathrm{R}$ & $\mathrm{R}$ & $\mathrm{R}$ & $\mathrm{R}$ & $\mathrm{R}$ & $\mathrm{R}$ \\
\hline 353 & & $\mathrm{~A} 1$ & $\mathrm{R}$ & $\mathrm{S}$ & $\mathrm{S}$ & $\mathrm{R}$ & $\mathrm{R}$ & $\mathrm{R}$ & $\mathrm{R}$ & $\mathrm{R}$ & $\mathrm{R}$ & $\mathrm{R}$ \\
\hline 355 & & A1 & $\mathrm{R}$ & $\mathrm{S}$ & $\mathrm{S}$ & $\mathrm{R}$ & $\mathrm{R}$ & $\mathrm{R}$ & $\mathrm{R}$ & $\mathrm{R}$ & $\mathrm{R}$ & $\mathrm{R}$ \\
\hline 357 & & A1 & $\mathrm{R}$ & S & $\mathrm{S}$ & $\mathrm{R}$ & $\mathrm{R}$ & $\mathrm{R}$ & $\mathrm{R}$ & $\mathrm{R}$ & $\mathrm{R}$ & $\mathrm{R}$ \\
\hline 358 & & A1 & $\mathrm{S}$ & $\mathrm{S}$ & $\mathrm{S}$ & $\mathrm{R}$ & S & $\mathrm{R}$ & $\mathrm{R}$ & $\mathrm{R}$ & $\mathrm{R}$ & $\mathrm{R}$ \\
\hline 360 & & $\mathrm{~A} 1$ & $\mathrm{R}$ & $\mathrm{S}$ & $\mathrm{S}$ & $\mathrm{R}$ & $\mathrm{R}$ & $\mathrm{R}$ & $\mathrm{R}$ & $\mathrm{R}$ & $\mathrm{R}$ & $\mathrm{R}$ \\
\hline 364 & & A1 & $\mathrm{R}$ & S & $\mathrm{S}$ & $\mathrm{R}$ & $\mathrm{R}$ & $\mathrm{R}$ & $\mathrm{R}$ & $\mathrm{R}$ & $\mathrm{R}$ & $\mathrm{R}$ \\
\hline 365 & & $\mathrm{~A} 1$ & $\mathrm{R}$ & $\mathrm{S}$ & $\mathrm{S}$ & $\mathrm{R}$ & $\mathrm{R}$ & $\mathrm{R}$ & $\mathrm{R}$ & $\mathrm{R}$ & $\mathrm{R}$ & $\mathrm{R}$ \\
\hline 367 & & A1 & $\mathrm{R}$ & S & $\mathrm{S}$ & $\mathrm{R}$ & $\mathrm{R}$ & $\mathrm{R}$ & $\mathrm{R}$ & $\mathrm{R}$ & $\mathrm{R}$ & $\mathrm{R}$ \\
\hline 368 & & A1 & $\mathrm{R}$ & $\mathrm{S}$ & $\mathrm{S}$ & $\mathrm{R}$ & $\mathrm{R}$ & $\mathrm{R}$ & $\mathrm{R}$ & $\mathrm{R}$ & $\mathrm{R}$ & $\mathrm{R}$ \\
\hline 375 & & A1 & $\mathrm{R}$ & S & $\mathrm{S}$ & $\mathrm{R}$ & $\mathrm{R}$ & $\mathrm{R}$ & $\mathrm{R}$ & $\mathrm{R}$ & $\mathrm{R}$ & $\mathrm{R}$ \\
\hline 377 & & A5 & $\mathrm{R}$ & $S$ & $\mathrm{~S}$ & $\mathrm{R}$ & $\mathrm{R}$ & $\mathrm{R}$ & $\mathrm{R}$ & $\mathrm{R}$ & $\mathrm{R}$ & $\mathrm{R}$ \\
\hline 378 & & A1 & $\mathrm{R}$ & S & $\mathrm{S}$ & $\mathrm{R}$ & $\mathrm{R}$ & $\mathrm{R}$ & $\mathrm{R}$ & $\mathrm{R}$ & $\mathrm{R}$ & $\mathrm{R}$ \\
\hline 383 & & A1 & $\mathrm{R}$ & S & $\mathrm{S}$ & $\mathrm{R}$ & $\mathrm{R}$ & $\mathrm{R}$ & $\mathrm{R}$ & $\mathrm{R}$ & $\mathrm{R}$ & $\mathrm{R}$ \\
\hline 389 & & A1 & $\mathrm{S}$ & $\mathrm{S}$ & $\mathrm{S}$ & $\mathrm{R}$ & $\mathrm{S}$ & $\mathrm{R}$ & $\mathrm{R}$ & $\mathrm{R}$ & $\mathrm{R}$ & $\mathrm{R}$ \\
\hline 408 & UB & A6 & $\mathrm{R}$ & $\mathrm{S}$ & $\mathrm{S}$ & $\mathrm{R}$ & $\mathrm{R}$ & $\mathrm{R}$ & $\mathrm{R}$ & $\mathrm{R}$ & $\mathrm{R}$ & $\mathrm{R}$ \\
\hline 431 & & G & $\mathrm{R}$ & $\mathrm{S}$ & $\mathrm{S}$ & $\mathrm{S}$ & $\mathrm{R}$ & $\mathrm{R}$ & $\mathrm{R}$ & $\mathrm{R}$ & $\mathrm{R}$ & $\mathrm{R}$ \\
\hline 462 & & $\mathrm{H}$ & $\mathrm{S}$ & S & $\mathrm{S}$ & $\mathrm{R}$ & $\mathrm{R}$ & $\mathrm{R}$ & $\mathrm{R}$ & $\mathrm{R}$ & $\mathrm{R}$ & $\mathrm{R}$ \\
\hline 481 & & B & $\mathrm{R}$ & S & $\mathrm{S}$ & $\mathrm{S}$ & $\mathrm{R}$ & $\mathrm{R}$ & $\mathrm{R}$ & $\mathrm{R}$ & $\mathrm{R}$ & $\mathrm{R}$ \\
\hline 485 & & B & $\mathrm{R}$ & $S$ & $\mathrm{~S}$ & $\mathrm{R}$ & $\mathrm{R}$ & $\mathrm{R}$ & $\mathrm{R}$ & $\mathrm{R}$ & $\mathrm{R}$ & $\mathrm{R}$ \\
\hline 486 & & A1 & $\mathrm{R}$ & $\mathrm{S}$ & $\mathrm{S}$ & $\mathrm{R}$ & $\mathrm{R}$ & $\mathrm{R}$ & $\mathrm{R}$ & $\mathrm{R}$ & $\mathrm{R}$ & $\mathrm{R}$ \\
\hline 506 & UEL & A7 & $\mathrm{R}$ & S & $\mathrm{S}$ & $\mathrm{R}$ & $\mathrm{R}$ & $\mathrm{R}$ & $\mathrm{R}$ & $\mathrm{R}$ & $\mathrm{R}$ & $\mathrm{R}$ \\
\hline 513 & & A1 & $\mathrm{R}$ & $S$ & $\mathrm{~S}$ & $\mathrm{R}$ & $\mathrm{R}$ & $\mathrm{R}$ & $\mathrm{R}$ & $\mathrm{R}$ & $\mathrm{R}$ & $\mathrm{R}$ \\
\hline 521 & & A1 & $\mathrm{R}$ & $\mathrm{S}$ & $\mathrm{S}$ & $\mathrm{R}$ & $\mathrm{R}$ & $\mathrm{R}$ & $\mathrm{R}$ & $\mathrm{R}$ & $\mathrm{R}$ & $\mathrm{R}$ \\
\hline 541 & & A1 & $\mathrm{R}$ & $\mathrm{S}$ & $\mathrm{S}$ & $\mathrm{R}$ & $\mathrm{R}$ & $\mathrm{R}$ & $\mathrm{R}$ & $\mathrm{R}$ & $\mathrm{R}$ & $\mathrm{R}$ \\
\hline 555 & & $\mathrm{~A} 1$ & $\mathrm{R}$ & $S$ & $\mathrm{~S}$ & $\mathrm{R}$ & $\mathrm{R}$ & $\mathrm{R}$ & $\mathrm{R}$ & $\mathrm{R}$ & $\mathrm{R}$ & $\mathrm{R}$ \\
\hline 578 & & A1 & $\mathrm{R}$ & $\mathrm{S}$ & $\mathrm{S}$ & $\mathrm{R}$ & $\mathrm{R}$ & $\mathrm{R}$ & $\mathrm{R}$ & $\mathrm{R}$ & $\mathrm{R}$ & $\mathrm{R}$ \\
\hline
\end{tabular}

*The disk diffusion test was performed with the following antimicrobial drugs: clindamycin (Cl) $2 \mu \mathrm{g}$, mupirocin (Mup) $5 \mu \mathrm{g}$, vancomycin (Vc) $30 \mu \mathrm{g}$, trimethoprim-sulphamethoxazole (Sft) $1.25-23.75 \mu \mathrm{g}$, ciprofloxacin (Cip) $5 \mu \mathrm{g}$, chloramphenicol (Co) $30 \mu \mathrm{g}$, gentamicin (Gn) $10 \mu \mathrm{g}$, oxacillin (Ox) $1 \mu \mathrm{g}$, penicillin (Pn) $10 \mathrm{U}$, tetracycline (Tc) $30 \mu \mathrm{g}$.

${ }^{\dagger}$ IFF, milk bank at Instituto Fernandes Figueira, Rio de Janeiro; MEJC, milk bank at Maternidade Escola Januario Cicco, Natal; MEAC, milk bank at Maternidade Escola Assis Chateaubriant, Fortaleza; UB, milk bank at Universidade de Brasília; UEL, milk bank at Universidade Estadual de Londrina. ${ }^{\$}$ PFGE was carried out as described previously [2]. The criteria used to classify MRSA clones were also as described previously[25]. 


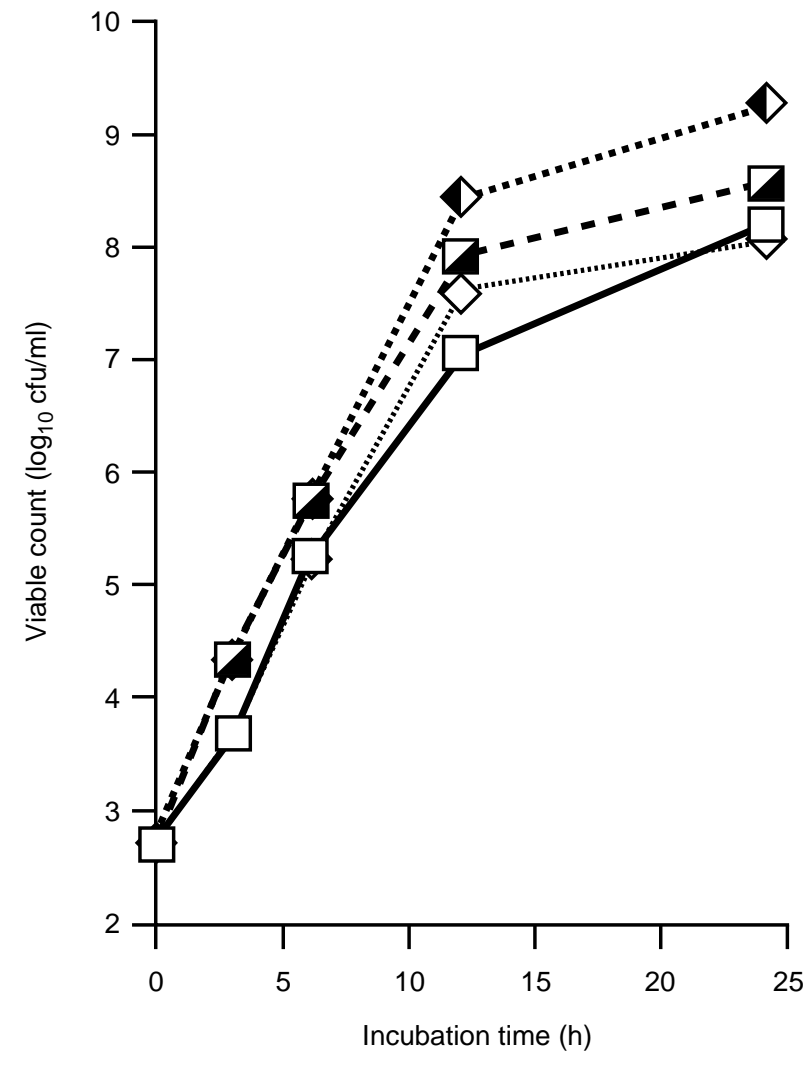

Fig. 2. Bacterial growth of strain $166(\square)$ and strain 355 $(\diamond)$ incubated in colostrum $(\square, \diamond)$ or trypticase soy broth $(\square, \triangleright)$.

collection techniques. It is very striking that most of these MRSA-contaminated milk samples (54 of 57) would be acceptable for dispensing as raw milk according to all the bacteriological criteria recommended by either the Brazilian or American guidelines $[18,19]$. Although additional studies were not performed, the differences in the percentage of MRSA contamination among different milk banks are likely to be due to different MRSA colonisation rates among patients in these hospitals.

The present study did not include an epidemiological survey to investigate the source of MRSA contamination in the milk samples analysed. The hypothesis that the mothers' breasts, and subsequently the milk samples, had been colonised by the sick babies in the nursery, who had already been colonised or infected with MRSA, was very unlikely, as only a small proportion of the milk donors had premature babies. However, low levels of MRSA contamination by the staff handling the samples could have occurred. Also, the possibility that the source of maternal contamination was their suckling healthy infants, previously colonised by MRSA in the hospital, cannot be excluded.

A limitation of this study was the lack of a systematic collection and analysis of risk factors for MRSA contamination of breast milk. However, it is concei- vable that the high frequency of MRSA contamination of human milk observed in this survey might be due to the facts that, in Brazil, many women deliver in hospitals and that caesarean section is a very frequent medical practice [29]. These practices contribute to a prolonged period of hospitalisation and frequent antimicrobial usage, both important factors known to increase the probability of developing MRSA colonisation among hospitalised patients. However, this proportion of MRSA contamination could also be related to the use of an enrichment broth containing methicillin for the detection of very small resistant subpopulations [30]. Previous results from this laboratory (F.R. Silva and A.M.S. Figueiredo, unpublished observations) showed that the use of this enrichment medium allowed a higher detection rate of methicillin resistance among staphylococcal isolates obtained from the anterior nose of human carriers $(29 \%)$ when compared with conventional methods for isolation of staphylococci and detection of methicillin resistance $(4.4 \%)$.

To determine if the MRSA-contaminated milk samples were harbouring the widespread Brazilian epidemic clone, the genome of 57 isolates was cut with the endonuclease SmaI and analysed by PFGE. Although a combination of two other methods, mecA-ClaI and $m e c A-T n 554$, have been used previously in this laboratory $[8,26,27,30,31]$, the validity of these methods to analyse clonality is now being questioned because of low discriminatory power. This conclusion has also been reached by others [32], who found restriction fragment length polymorphism methods with mec gene-associated loci (i.e., mecA and Tn554) less discriminatory than some phenotypic methods for typing, e.g., the disk diffusion test. PFGE has been recommended as the typing method of choice for MRSA isolates [25, 32].

On the basis of PFGE patterns, the great majority of milk samples contaminated with MRSA contained strains belonging to the Brazilian epidemic clone [27]. This clone has been the cause of MRSA hospital epidemics in Brazil and other South American countries since 1992 and remains the most common MRSA isolate in different cities [26, 27]. Recently, this clone was reported in three Portuguese hospitals, suggesting inter-continental transfer of this strain from Brazil to Portugal [28]. Of concern is the fact that some isolates belonging to the Brazilian epidemic clone have acquired mupirocin resistance through the acquisition of the novel ileS gene in a large plasmid, which might impair the future use of mupirocin in nasal decolonisation, as an MRSA infection control measure, in South American and Portuguese hospitals [31]. In addition, bacteria from this MRSA clonal type present multiresistant profiles, being frequently susceptible to vancomycin only [27].

Although MRSA is a frequent cause of epidemics in NICU $[3,33]$ and outbreaks of MRSA infections in 
a

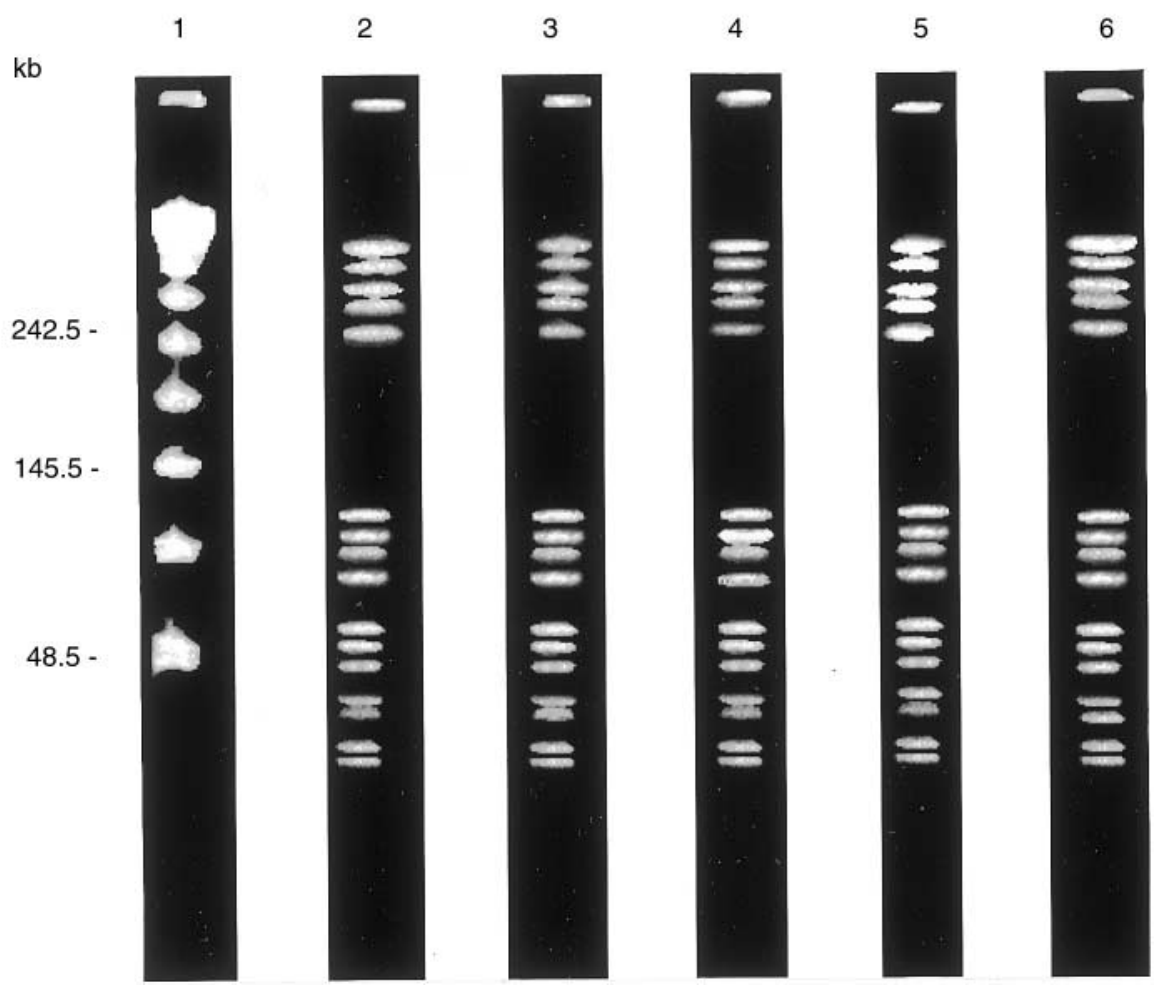

b

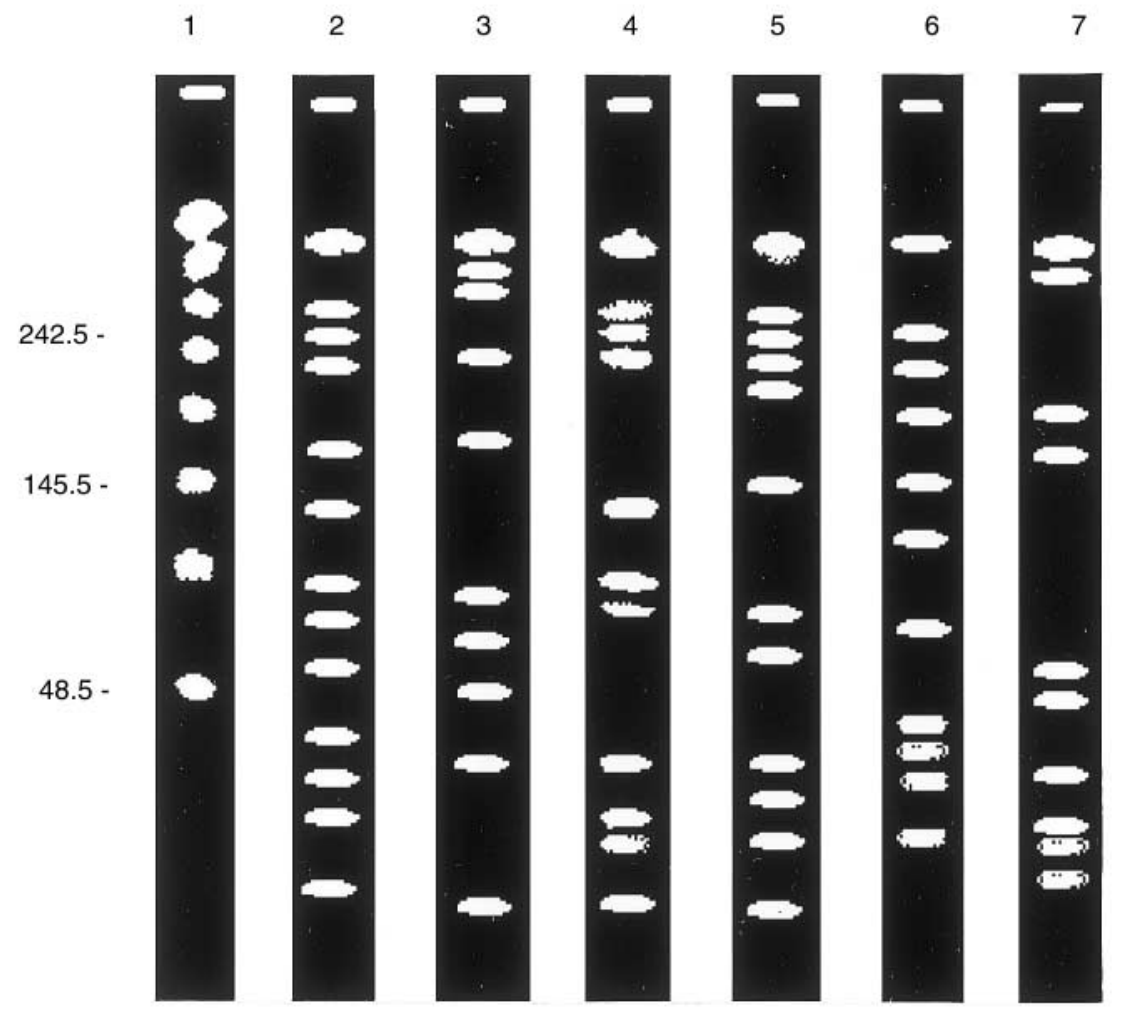

Fig. 3. PFGE of MRSA isolates from expressed breast milk, after digestion of chromosomal DNA with the endonuclease SmaI. (a) PFGE from strains belonging to the Brazilian epidemic clone. Lane 1, $\lambda$ ladder; 2, strain BMB5292 (a representative of the Brazilian epidemic clone [27]); 3, strain 278; 4, strain 340; 5, strain 486; 6, strain 578. (b) PFGE of sporadic MRSA clones isolated from breast milk. Lane 1, $\lambda$ ladder; 2, strain 120; 3, strain 121; 4, strain $149 ; \mathbf{5}$, strain $296 ; \mathbf{6}$, strain $431 ; \mathbf{7}$, strain 462 . 
immunocompromised patients (including premature and new-born infants) are a serious problem, few studies have been carried out to assess the mechanisms of transmission and the epidemiology of MRSA colonisation and infection in this susceptible population.

Hollis et al. [11] suggested that family members may be an important reservoir for transmission of MRSA to high-risk neonates. In the UK, during a maternity hospital outbreak of MRSA [10], it was reported that significant environmental contamination and a very high risk rate of maternal perineal MRSA colonisation seemed to be important epidemiological features. In another study involving a total of 2576 neonates from Singapore hospitals, over a period of 20 months, it was reported that $30 \%$ of neonates colonised with MRSA had acquired infections and c. $20 \%$ of the infections were septicaemia or septicaemia with osteomyelitis [33].

In addition to the fact that MRSA isolation is increasing among paediatric patients [10], some outbreaks in neonatal units remain uncontrolled despite infection control measures [33,34]. Although motherto-infant transmission of MRSA has been described [11], only two reports on breast milk as a potential source of transmission of MRSA to infants were found. In 1987 it was reported that maternal breast milk was the possible source of transmission of MRSA to a baby who died with CNS infection in a special care baby unit in the UK [35]. Also, in the same year, MRSA transmitted by breast milk was incriminated as the possible cause of an outbreak in a neonatal unit in another hospital in the UK [36].

Torres-Goitia et al. [37] observed that bacteria from mothers' skin flora were inhibited by breast milk. However, the same authors observed that it did not have the same bacteriostatic and bactericidal properties to protect against contamination by bacteria that did not belong to the mothers' flora; e.g., those from the nurse aids' hands. These data would explain why colostrum had little or no effect on the growth of MRSA isolates from the Brazilian epidemic clone. As MRSA is a transient member of the flora, it is likely to be acquired by the mothers during their hospitalisation to give birth. Thus, it is conceivable that the mother's milk does not provide, in this case, enough inhibitory protection against MRSA isolates. In another study, with low birth weight infants, it was found that breast milk did not impair intestinal $S$. aureus colonisation in c. $22 \%$ of the babies studied. The proportion of $S$. aureus colonisation for babies that were being fed with 'humanised' powdered cow's milk was c. 35\% [38].

Due to the large distances among the cities where the milk banks were located and the lack of information about the patients' histories in most of the associated hospitals studied, it was not possible to follow-up the babies that received MRSA-contaminated breast milk, to look for MRSA infections. However, since it has been reported that new-born babies and pre-term infants are immunocompromised hosts and that to be a MRSA carrier implies a high risk of MRSA infection, it is likely that feeding babies with MRSAcontaminated breast milk would contribute to the increase of MRSA outbreaks in neonatal units.

The fact that the milk samples analysed would meet all criteria to be dispensed as raw milk shows that the risk of MRSA contamination in breast milk is not caused by poor quality control at Brazilian milk banks. However, it seems that there is an urgent need to improve quality control as regards MRSA contamination. Also, the implication of breast milk as a possible cause of hospital neonatal infections, in at least two hospitals in the UK in 1987, when MRSA incidence was still low, strongly suggests that this issue is not a local problem. Also, breast milk contamination might have been underestimated by the poor sensitivity of conventional methods to detect low concentrations of MRSA in the milk flora.

In conclusion, in view of the danger that a multiresistant MRSA clone represents to new-borns, and the difficulties of the control of MRSA infections, due to the spread of multiresistant and epidemics clones, it is strongly recommended that selective enrichment broths with methicillin and agar screen tests should be adopted for detection of MRSA as part of the bacteriological control of breast milk to be dispensed raw. Additional studies are necessary to determine the source of contamination and the potential contribution of MRSA-contaminated breast milk in propagating MRSA colonisation and infection in nurseries.

This work was supported in part by a grant from Conselho Nacional de Desenvolvimento Científico e Tecnológico (CNPq), Ministério da Saúde (Brazil), Fundação Coordenação de Aperfeiçoamento de Pessoal de Nível Superior (Capes, Proim), Financiadora de Estudos e Projetos (FINEP/BID; FINEP/PRONEX; FINEP/FNDCT) and Fundação de Amparo à Pesquisa do Estado do Rio de Janeiro (FAPERJ).

\section{References}

1. Asquith MT, Harrod JR. Reduction of bacterial contamination in banked human milk. J Pediatr 1979; 95: 993-994.

2. Soares MJS, Tokumaru-Miyazaki NH, Noleto ALS, Figueiredo AMS. Enterotoxin production by Staphylococcus aureus clones and detection of Brazilian epidemic MRSA clone (III::B:A) among isolates from food handlers. J Med Microbiol 1997; 46: 214-221

3. Farrington M, Ling J, Ling T, French GL. Outbreak of infection with methicillin-resistant Staphylococcus aureus on neonatal and burn units of a new hospital. Epidemiol Infect 1990; 105: 215-228.

4. Price EH, Brain A, Dickson JA. Outbreak of infection with a gentamicin and methicillin-resistant Staphylococcus aureus in a neonatal unit. J Hosp Infect 1980; 1: 221-228.

5. Reboli AC, John JF, Levkoff AH. Epidemic methicillingentamicin-resistant Staphylococcus aureus in a neonatal intensive care unit. Am J Dis Child 1989; 143: 34-39.

6. Richardson JF, Quoraishi AH, Francis BJ, Marpless RR. Beta- 
lactamase-negative, methicillin-resistant Staphylococcus aureus in a newborn nursery: report of an outbreak and laboratory investigations. J Hosp Infect 1990; 16: 109-121.

7. Jarvis WR, Thornsberry C, Boyce J, Hughes JM. Methicillinresistant Staphylococcus aureus at children's hospitals in the United States. Pediatr Infect Dis 1985; 4: 651-655.

8. Noel GJ, Kreiswirth B, Edelson PJ et al. Multiple methicillinresistant Staphylococcus aureus strains as a cause for a single outbreak of severe disease in hospitalized neonates. Pediatr Infect Dis $J$ 1992; 11: 184-188.

9. Moore EP, Williams EW. A maternity hospital outbreak of methicillin-resistant Staphylococcus aureus. J Hosp Infect 1991; 19: 5-16.

10. Back NA, Linnermann CC, Staneck JL, Kotagal UR. Control of methicillin-resistant Staphylococcus aureus in a neonatal intensive-care unit: use of intensive microbiologic surveillance and mupirocin. Infect Control Hosp Epidemiol 1996; 17: 227231.

11. Hollis RJ, Barr JL, Doebbeling BN, Pfaller MA, Wenzel RP. Familial carriage of methicillin-resistant Staphylococcus aureus and subsequent infection in a premature neonate. Clin Infect Dis 1995; 21: 328-332.

12. Muder RR, Brennen C, Wagener MM et al. Methicillinresistant staphylococcal colonization and infection in a longterm care facility. Ann Intern Med 1991; 114: 107-112.

13. Tveten Y, Kristiansen BE, Ask E, Jenkins A, Hosfstad T. DNA fingerprinting of isolates of Staphylococcus aureus from newborns and their contacts. J Clin Microbiol 1991; 29: $1100-1105$.

14. Mitao M, Hamada T, Hirai G. [Infection route of MRSA to pregnant women and to newborns.] Nippon Sanka Fujinka Gakkai Zasshi 1995; 47: 231-236.

15. Mitsuda T, Arai K, Fujita S, Yokota S. Demonstration of mother-to-infant transmission of Staphylococcus aureus by pulsed-field gel electrophoresis. Eur J Pediatr 1996; 155: 194199.

16. Beckholt AP. Breast milk for infants who cannot breast feed. $J$ Obstet Gynecol Neonatal Nurs 1989; 19: 216-220.

17. Byrne B, Hull D. Neonatal nutrition - breast milk for preterm infants. Prof Care Mother Child 1996; 6: 39-45.

18. BRASIL. Ministério da Saúde. Recomendações técnicas para o funcionamento de bancos de leite humano. Brasilia/DF. 1993.

19. Arnold LW, Tully MR. Guidelines for the establishment and operation of a donor human milk bank. Human milk banking - Association of North America. 1998.

20. Kloos WE, Schleifer KH. Genus IV. Staphylococcus. In: Sneath PHA, Mair NS, Sharpe ME, Holt JG (eds) Bergey's manual of systematic bacteriology, vol 2. Baltimore, Williams \& Wilkins. 1996: 1013-1035.

21. de Lencastre H, Sa Figueiredo AM, Urban C, Rahal J, Tomasz A. Multiple mechanisms of methicillin resistance and improved methods for detection in clinical isolates of Staphylococcus aureus. Antimicrob Agents Chemother 1991; 35: 632-639.

22. National Committee for Clinical Laboratory Standards. Performance standards for antimicrobial disk susceptibility tests, 5 th edn. (NCCLS publication v.13 no. 24.) Vilanova, PA, National Committee for Clinical Laboratory Standards. 1993.

23. Sambrook J, Fristch EF, Maniatis T. Molecular cloning. A laboratory manual, 2nd edn. Cold Spring Harbor, NY, Cold Spring Harbor Laboratory Press. 1989.
24. Matthews PR, Reed KC, Stewart PR. The cloning of chromosomal DNA associated with methicillin and other resistances in Staphylococcus aureus. J Gen Microbiol 1987; 133: $1919-1929$.

25. Goering RV, Tenover FC. Epidemiological interpretation of chromosomal macro-restriction fragment patterns analyzed by pulsed-field gel electrophoresis. J Clin Microbiol 1997; 35: 2432-2433.

26. Coimbra MVS, Klan L, Figueiredo AMS. Tracking the Epidemic Multiresistant Staphylococcus aureus clone III::B:A in South America Countries. 37th Interscience Conference on Antimicrobial Agents and Chemotherapy. Toronto, Canada. 1997: 114.

27. Teixeira LA, Resende CA, Ormonde LR et al. Geographic spread of epidemic multiresistant Staphylococcus aureus clone in Brazil. J Clin Microbiol 1995; 33: 2400-2404.

28. De Souza MA, Santos Sanches I, Ferro ML et al. 1998 Intercontinental spread of a multidrug-resistant methicillinresistant Staphylococcus aureus clone. J Clin Microbiol 1998; 36: $2590-2596$.

29. Gentile FP, Filho GN, Cunha AA. The relationship between payment for child birth care and prevalence of cesarean sections in maternity hospitals in Rio de Janeiro: a review of Carlos Gentile de Mello's hypothesis. Caderno de Saúde Pública (RJ) 1997; 13: 221-226.

30. Falcão MHL, Borges-Neto AA, Fracalanzza SEL, Seldin L, Figueiredo AMS. Associations of methicillin-resistant and susceptible strains of Staphylococcus aureus isolated from the same colonization site from healthy humans in Rio de Janeiro. Abstracts of the 94th General Meeting of the American Society for Microbiology. 1994: 563.

31. Ramos RLB, Teixeira LA, Ormonde LR et al. Emergence of mupirocin resistance in multiresistant Staphylococcus aureus clinical isolates belonging to Brazilian epidemic clone III::B:A. J Med Microbiol 1999; 48: 303-307.

32. Tenover FC, Arbeit R, Archer G et al. Comparison of traditional and molecular methods of typing isolates of Staphylococcus aureus. J Clin Microbiol 1994; 32: 407-415.

33. Tan KW, Tay L, Lin SH. An outbreak of methicillin-resistant Staphylococcus aureus in a neonatal intensive care unit in Singapore: a 20-month study of clinical characteristics and control. Singapore Med J 1994; 35: 277-282.

34. Zafar AB, Butler RC, Reese DJ, Gaydos LA, Mennonna PA. Use of $0.3 \%$ triclosan (Bacti-Stat) to eradicate an outbreak of methicillin-resistant Staphylococcus aureus in a neonatal nursery. Am J Infect Control 1995; 23: 200-208.

35. Lemoine L. Possible transmission of methicillin-resistant Staphylococcus aureus by expressed human milk. $J$ Hosp Infect 1987; 9: 93-94.

36. Cooke RPD, Devlin J, Robinson MJ. Breast milk and methicillin-resistant Staphylococcus aureus. J Hosp Infect 1987; 10: 312.

37. Torres-Goitia J, Fernandez P, Ferreiro M, Rizzardini M, Fernandez R. [Maternal lactation. I. Resistance of maternal milk to bacterial contamination.] Bol Med Hosp Infant Mex 1979; 36: 599-604.

38. Fernandez P, Torres-Goitia J, Ferreiro M, Rizzardini M. [Maternal lactation. II. Intestinal colonization in breast fed newborn infants.] Bol Med Hosp Infant Mex 1979; 36: 605610 . 